\title{
Mr. and Mrs. S. C. Hall: Their Papers at Iowa
}

\author{
JAMES NEWCOMER
}

\begin{abstract}
"Although we have endeavoured by every means within our reach to secure accuracy in those portions of our Book where accuracy is most essential, we cannot doubt that some errors will have occurred in the course of these papers, - and will thankfully acknowledge our obligations to [anyone] who will point out such errors for correction hereafter."
\end{abstract}

Mr. and Mrs. S. C. Hall in "Advertisement," A Week at Killarney.

I offer this paper in the Halls' spirit. It is not a work of meticulous scholarship. It is meant only to establish a toehold on the subject, to be a report of work in progress, to invite attention to worthy writers who have been largely forgotten. They are worth the effort.

My interest in Mr. and Mrs. S. C. Hall derived from my study of Maria Edgeworth and Lady Morgan. From the publication of my two books on Maria Edgeworth ${ }^{1}$ she received more and more of the critical attention she deserved. Lady Morgan studies have been few and far between; but perhaps publication of my book on her by the Dolmen Press ${ }^{2}$ will augur increased interest in her and her work. It was the frequent references to Mrs. Hall that I encountered in studying Edgeworth and Morgan that stirred my curiosity and led to my investment of time and study in her multitudinous works and, incidentally, those of her husband.

Were Edgeworth, Morgan, and Mrs. Hall Irish writers? To ask is to beg the question. Irish nationalists (however they are defined) will object vehemently. ${ }^{3}$ Edgeworth was born in England (1768) and came to Ireland to live when she was fourteen or fifteen. Anna Maria Fielding Hall was born in Ireland (1800), only to leave Ireland at the age of fifteen, never to live there again. Lady Morgan never told the truth about

${ }^{1}$ Maria Edgeworth the Novelist (Fort Worth: Texas Christian University Press, 1967), and Maria Edgeworth (Bucknell, Bucknell University Press, 1971).

${ }^{2}$ Lady Morgan the Novelist (Dublin, The Dolmen Press, in press).

${ }^{3}$ Concerning George Moore: "Born of Irish gentry in Mayo in 1852 . . . Moore spent much time in Paris and London. Many Dubliners, considering him an outsider, thought it a preposterous joke that he should contemplate writing an epic of Irish life." From an advertisement by the Catholic University of America Press, Fall 1984, p. 1. 
herself if she could help it; she was born probably in 1776, perhaps on a boat returning to Ireland from England. Edgeworth had not one drop of native Irish blood, though her Edgeworth forbears had been in Ireland since Elizabeth's time. Morgan had not more than one-quarter of native Irish blood; her mother was English and her father's mother Irish of English extraction. Both Mr. and Mrs. Hall were born in Ireland, but probably had no Irish blood.

Yet all three of the women called themselves Irish women. Their best writing dealt with Ireland. Their interests were Irish. Their sympathies were Irish. Intelligent and generous, all three, they made the best interests of Ireland their interest. Let me sweep all objection aside and call them Irish.

And now to look at Mr. and Mrs. S. C. Hall.

The marriage of Anna Maria Fielding and Samuel Carter Hall lasted almost 57 years. Two people of intelligence and character shared love, affection, confidence, professional interests, and friendships. They were denied the blessing of children: Mr. Hall writes that on the monument to his father is inscribed "the name of Maria Louisa, the only child we had who lived, and her life on earth was very brief." 4

The importance of happy marriage and the values of family life inform everything that they wrote. They appear more obviously and more frequently in the fiction of Mrs. Hall, where they are everywhere integral to character and action. There is significance in the fact that Mrs. S. C. Hall used no other name. There was no bound to her intellectual independence and awareness of her selfhood. But independence and selfhood offered no contradiction, in her opinion, to the primacy of marriage and husband. In art and literature their standards of man and wife were the same. In social life they valued and cultivated the same friends. Their tastes were similar in the details of home life. In the surrender that each made to the other, each seemed to find the independent and full realization of his own personality.

Their efforts to help others were persistent and generous. They worked hard to promote temperance in drinking. She was ardent in the support of women's rights. She helped found and wrote in support of a hospital for consumptives, the Governesses' Institute, the Home for Decayed Gentlewomen, the Nightingale Fund; contributed special efforts to special charities; worked indefatigably in fund-raising efforts for this, that, and the other good work. In all these her husband gave encouragement and support, as she gave encouragement to him.

${ }^{4}$ Retrospect of a Long Life: From 1815 to 1883 (London: Richard Bentley and Son, 1883), II, 486. 
All this was carried on while both wrote and edited to a degree matched by few other writers. The moment of recognition of the prodigious amount of writing that they did is a moment of decisionshould one attack such a vast amount of material, or should one take a subject more accessible, more manageable, one for whose study there could be an end in sight? "Mrs. Hall wrote no less than 250 books, counting those she edited and numerous temperance tracts." I have not counted them, but I shall not contradict the figure. Someone has said that together Mr. and Mrs. Hall had some share in the production of no fewer than 500 titles. The student of the Halls cannot be contented with reading less than the entire amount that they wrote, which is only to say that I shall not find a final contentment in my study of the Halls.

Books by Mrs. Hall were not immediately accessible to me. They seldom appeared in the secondhand or rare book catalogs. Having ascertaine 1 that the Cambridge University Library held a goodly number, I took myself there for a total of nine months, in two separate visits, and immersed myself in the reading of Mrs. Hall. Three-quarters or more of the books are in the Rare Books Room, to be read only there; there have not been new editions. The holdings there amount to some 32 titles and 46 volumes (not counting duplicates). Add the six titles and nine volumes written by Mrs. Hall in collaboration, and we find a total of 38 titles and 55 volumes at Cambridge. How small a number in comparison with the whole of her writing! And yet enough to provide years of study.

Having to make an attack on the problem, I chose to start with The Whiteboy. ${ }^{6}$ It is a novel written in 1845 . The time of the action is 1822 . Its general subject is a disastrous action by Irish rebels against the English. And I was facing, once again, in a forgotten novel, the essential subject of Irish fiction writers since Maria Edgeworth's time. In The Whiteboy, once again, are those fundamental oppositions between native Irish and Anglo-Irish, Ireland and England, Catholic and Protestant, loyal and disloyal. Here, once again, human values are tested by the agonies of political and social realities. Here are portrayed, in the genre of the novel, the very issues of the two Irelands in the 1980s that rend our hearts and confound our reason.

The Irish tragedy begs for solution. The fatal flaw within this tragedy is the inability, on each side of the conflict, of those whose hearts and minds are most engaged to recognize and accept enough sympathy for

${ }^{5}$ C. J. Hamilton, Notable Irishwomen (Dublin: Sealy, Bryers, and Walker, n.d.), p. 131. This figure is taken from S. C. Hall, Retrospect of a Long Life (London: Richard Bentley and Son, 1883).

'My essay called "Mrs. Samuel Carter Hall and The Whiteboy" appeared in Etudes Irlandaises, December 1983, Université de Lille. 


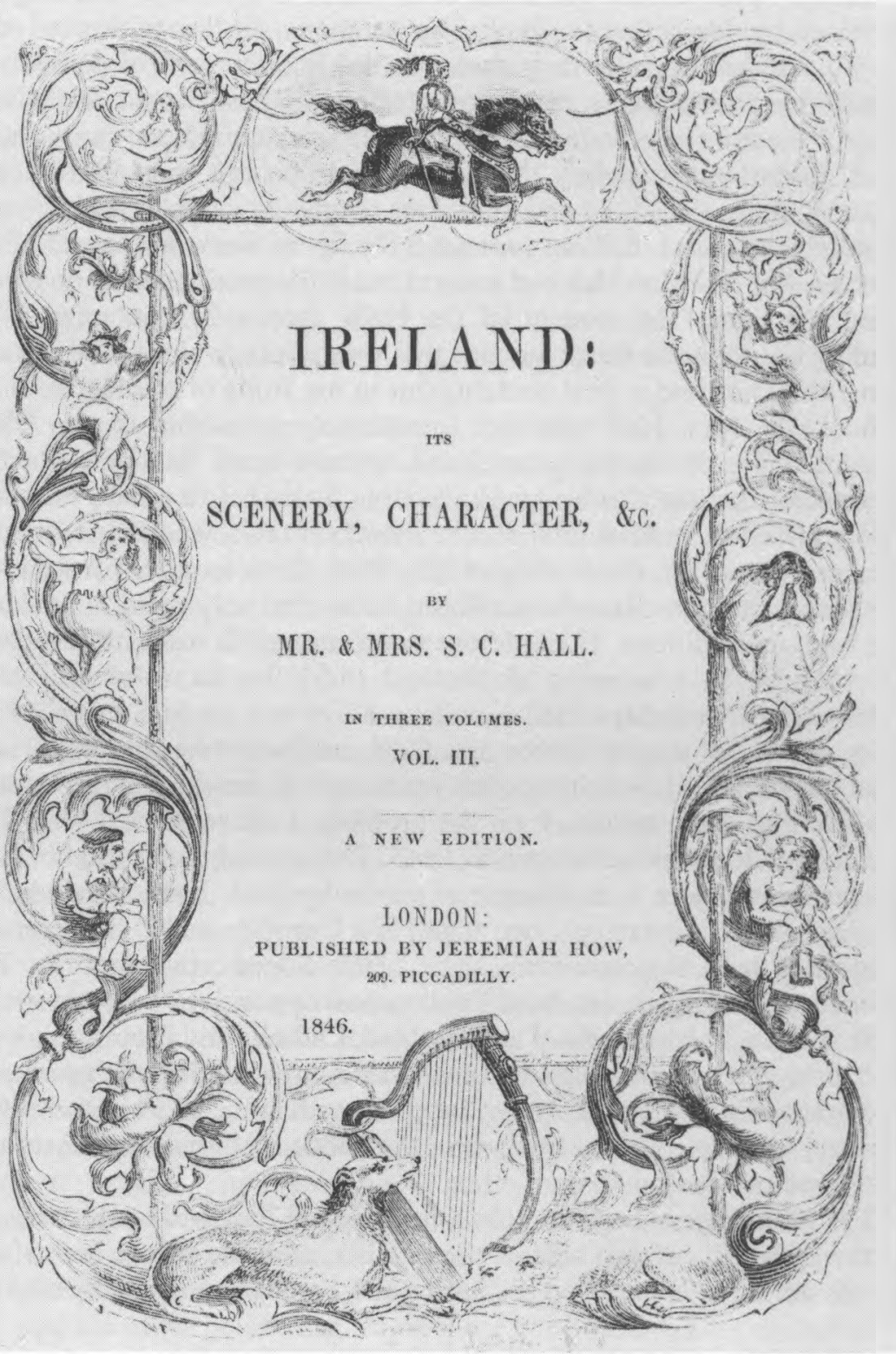

Title page of one volume from a three-volume work on Ireland by Mr. and Mrs. Hall. From a copy presented to The University of Iowa Libraries in 1978 by Professor William O. Aydelotte. 


\title{
THE
}

\section{BOOK OF GEMS.}

THE

\author{
MODERN POETS AND ARTISTS OF
}

GREAT BRITAIN.

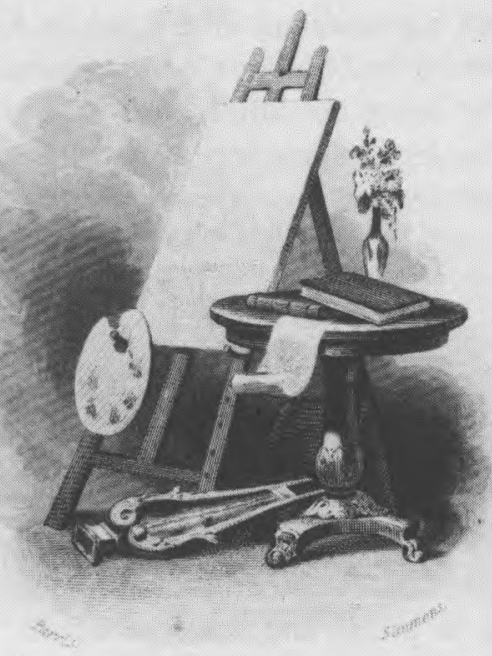

EDITED BY S. C. HALL

\section{LONDON}

WHITTAKER AND CO. AVE MARIA LANE

\section{8}

Title page of the third volume of S. C. Hall's The Book of Gems (1837-38), a three-volume anthology of British poetry illustrated by noted artists of the time (e.g., Edwin Landseer, J. M. W. Turner, John Martin, Thomas Stothard, and Benjamin R. Haydon), with biographical and critical notes. Leigh Hunt contributed to the notes on Keats, Shelley, and Tennyson, and Hunt's poem "Abou ben Adhem" had its first publication in this volume. 
the opponent to facilitate a solution. They see the problem only in political and social terms. Edgeworth, Morgan, and Hall perceive a third dimension, the moral.

It would be romantic, anti-intellectual, to say that they provide a solution. But what other solution is there? They offer a set of characters and situations that the partisan of either side would be incapable of conceiving. They do not set out to make Protestants out of Catholics, Irish Nationalists out of Northern Ireland Unionists. Their compassion is for human nature on both sides, for anyone who suffers. The objects of their dislike or contempt are unworthy of any more favorable attitude.

It is not in the novel, other than The Whiteboy, that Mrs. Hall focused her burning glass on the Irish. ${ }^{7}$ Most of her Irish fiction takes the form of the short story, as in Sketches of Irish Character and Stories of the Irish Peasantry. Her keen and sympathetic observations appear in a multitude of pages written with her husband in A Week in Killarney, Handbooks for Ireland, and Ireland, Its Scenery, Character, and History. She misses accuracy, perhaps by being too kindly, too generous, too appreciative; she romanticizes the Irish character, even as she lays open the Irish weaknesses and shortcomings for all her readers to see. But the sympathy is always there, inviting the English reader to share it and to temper his animosity and assuage his ignorance. If England never arrived at a wise and generous policy toward Ireland, if for 200 years and more she has paid a terrible price for her domination, Mrs. Hall is not to be blamed. What's more, the lessons that she teaches are still there, plain, to be seen and learned.

What does Mr. Hall say of his wife? "Her books were never popular in Ireland, though very popular in every other country. She tried-as she did by her bonnet-ribbons-to blend the orange and the green. She saw in each party much to praise and much to blame; but what one party approved the other condemned, and 'between two stools'- the adage is trite. Yet her stories are fertile of sympathy, generous, considerate, loving, and kind, pregnant with true wisdom, and indulgent as to faults on both sides-perhaps to excess ... It must suffice to say that she loved her country and its people dearly." 8

\footnotetext{
7 Available criticism from the past is not reliable. Consider: [Mrs. Hall's novel Marion, or a young Maid's Fortunes (1840) is] "the best of her novels . . . in which her knowledge of Irish character is again displayed in a style equal to anything by Maria Edgeworth." (From the Dictionary of National Biography.) This is simply not true. It is comparable to the idea that The Wild Irish Girl is the best of Lady Morgan's novels, an absolute error that prevailed in critical comment for a hundred years and more.

${ }^{8}$ William Henry Goss, The Life and Death of Llellynn lewitt (London: Henry Gray, 1884), p. 391.
} 
Mr. Hall is just-meaning that, judging by the books of Mrs. Hall that I have read, I agree with him. Whether one is reading Mr. or Mrs. Hall, one has the comfortable feeling of being in touch with someone perceptive, generous, intelligent, and just. In a portrait drawn by Paul de la Roche in 1847 he is dignified, with sharp features, sharp eyes, strong chin, firm mouth, with head drawn back proudly. A portrait of her drawn by Daniel Maclise in 1830 shows her with rounded full face, large eyes, well-arched brows, the suggestion of a double chin, hair in corkscrew curls almost to her shoulders, parted in the center, slightly in disarray; apparently full bust; the suggestion of a smile and good humor; good nose, small mouth. If they came to my community as strangers, I should seek out their acquaintance.

Before leaving England I began a search for the Hall papers and manuscripts. I discovered, with some amusement, that a collection of them existed at The University of Iowa, where I had taken the Ph.D. degree in 1953. Upon inquiry, I was told this by Frank Paluka, head of Special Collections:

... we do not claim to be the major depository of Hall correspondence. Our holdings have been built up piecemeal over the years, building around the fact, I suppose, that the Halls were at least on the periphery of the Leigh Hunt circle. Our present estimate is that there are about 110 letters (some 360 pages) relating to Anna Maria Hall and perhaps 145 letters (some 235 pages) to or from Samuel Carter Hall.

My visit to the Iowa archives was long enough to prove that a careful sifting of the Hall papers would be valuable to the biographer or critic. Let me give a sampling.

The Halls, for all their idealism, knew the practical concerns and worries of business. They must have driven themselves decade after decade to produce as much as they did; and though they had an overall success, they had their worried moments. Mrs. Hall is a very concerned woman when she writes secretly about Mr. Hall's business situation. He is worried and depressed during negotiations with a Mr. Virtue over the making of copies of the Queen's Gallery pictures, the urgent need of

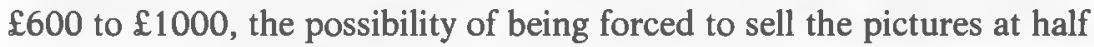
price, the threat of having to let their house, Firfield.

They both were concerned with getting publicity for their books, the neglect of reviewers, the indifference of the public. "Literary men time out of mind have been as flys to spider nets-this will continue to be the case until the state of society is changed-and literature takes its high and holy stance and is acknowledged as the power-it is now en rapport with all things_\& yet without a position of its own." [Mrs. Hall]

"I shall be greatly pleased to see a par. on my work in the Globe on 
Saturday: I take it in: and it does not take me in." [Mr. Hall]

"Thanks for your last letter also: I am very proud of the story and warm praise you gave me . . . The writer in the Globe . . . I wish he had given me a passage I could have quoted." [Mr. Hall]

“. . . Mr. Herbert Ingram would not permit any line of notice-much less praise of anything he [Mr. Hall] did:- to go into 'The Illustrated News.'-I do not know why the illustrious M.P. should so hate us-but it is evident he does. . . . were it not for the injury the prejudice does us - in the way of our breadwinning - I cannot say I should give a second thought, as to whether this great man-liked or disliked us-but 'The Illustrated' has a large circulation- \& $\&$ might do us a service-Could you get from Mr. Ingram why he is so bitter and unjust-and could you convince him that it is unjust-\& ungenerous-I am anxious that 'The Book of the Thames' in 'The Art Journal' should be noticed as it passes through its pages-It is downright affectation for literary persons to pretend that to care for fame-fame, is their food-in a double sense and they ought to cultivate it, not as a luxury to be looked at $\&$ bent to, but as a necessity - for the present, \& the future?-_" [Mrs. Hall]

There are examples of their generosity: "I could not rest until I had congratulated you on giving us such a bright invigorating story ... enriched by such morality." [Mrs. Hall] Of her definition of womanhood and her insistence on it: ". . . there is also about her the charm of womanship - developed more fully since her marriage-She is a tender-loving - and gentle wife-She is more-She is an understanding one." Of her generous religiosity: "I like people to be firm and faithful to whatever creed they profess-and a Roman Catholic - who holds as he or she ought to do-by his or her creed - can hold no faith with heretics." Of their fight for temperance. Of their belief in spiritualism.

Such illuminations in letters and journals sustain and substantiate interpretation and analysis of published works, or perhaps protect a critic from conclusions that the evidence cannot support.

After starting to write this paper I received from the head of Special Collections at Iowa the xerox copy of the manuscript of Mrs. Hall's story "Luke O'Brian," recently acquired. This is the only Hall manuscript that I have examined. This is no place to make a detailed analysis, but it points to some exciting possibilities. On the first short page are no fewer than 20 corrections that Mrs. Hall made in the original text. A glance shows that 16 pages will yield at least 320 corrections to be noted and considered. Even more interesting is the discovery that in the printed text that I own ${ }^{9}$ there are, in the first 30 lines, 30 changes from the Iowa

${ }^{9}$ Sketches of Irish Character (London: Nattali and Bond, 1855). 


\section{manuscript.}

The detailed study of the Mr. and Mrs. S. C. Hall manuscripts at Iowa is yet to be done. The value of such detailed analysis is yet to be determined. The world of scholarship has pretty much let Mr. and Mrs. Hall's writing fade into oblivion. ${ }^{10}$ As literary history this forgetfulness constitutes a loss to scholarship. As literature there is to be found in their immense production, I am pretty well convinced, a sufficient body of worthy literature to deserve critical attention and to merit perpetuation in the literary consciousness. The Hall papers at Iowa offer substantive material to determine and to temper critical appraisal of their writing.

10 Barry Sloan provides some correction to this state of affairs in his essay "Mrs. Hall's Ireland." Eire-Ireland, Fall 1984, p. 18. 